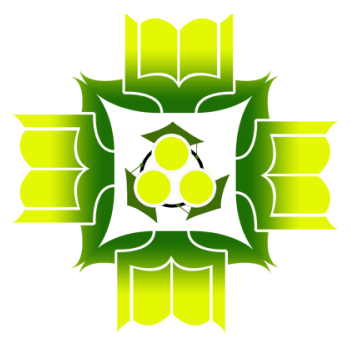

\title{
IMAGINATION AND CREATIVE THINKING SKILLS OF ELEMENTARY SCHOOL STUDENTS IN LEARNING MATHEMATICS: A REFLECTION OF REALISTIC MATHEMATICS EDUCATION
}

\author{
Imam Kusmaryono \\ Universitas Islam Sultan Agung \\ kusmaryono@unissula.ac.id \\ Hevy Risqi Maharani \\ Universitas Islam Sultan Agung \\ hevyrisqi@unissula.ac.id
}

\begin{abstract}
This research is a qualitative research based on classroom reports. The purpose of the study was to investigate the effect of the RME approach on the imagination and creative thinking abilities of elementary school students in solving math problems. The method of data collection was done through written tests, observations, and interviews. The participants in this study consisted of a class teacher, 36 grade 6 elementary school students, and an observer. The results showed that the application of the realistic mathematics education (RME) learning approach had a positive effect, namely encouraging the development of students' imaginative power and creative thinking skills in solving problems. The principles of RME are in line with the objectives of learning mathematics, namely to equip them with the ability to think logically, realistically, analytically, systematically, critically, and creatively.
\end{abstract}

Keywords: Imagination; Creative Thinking; Realistic Mathematics Education 


\begin{abstract}
Abstrak
Penelitian ini merupakan penelitian kualitatif berbasis classroom report. Tujuan penelitian untuk menyelidiki pengaruh pendekatan RME terhadap daya imajinasi dan kemampuan berpikir kreatif siswa sekolah dasar dalam menyelesaikan masalah matematika. Metode pengumpulan data dilakukan melalui tes tertulis, pengamatan, dan wawancara. Participant dalam penelitian ini terdiri dari seorang guru kelas, 36 siswa kelas 6 sekolah dasar, dan seorang pengamat. Hasil penelitian menunjukkan bahwa penerapan pendekataan pembelajaran realistic mathematics education (RME) memberi pengaruh positif yaitu mendorong berkembangnya daya imajinatif dan kemampuan berpikir kreatif siswa dalam memecahkan masalah. Prinsip-prinsip RME sejalan dengan tujuan pembelajaran matematika yaitu membekali mereka dengan kemampuan berpikir logis, realistis, analistis, sistematis, kritis, dan kreatif
\end{abstract}

Kata Kunci: Imajinasi, Berpikir Kreatif, Realistic Mathematics Education.

\title{
INTRODUCTION
}

Learning mathematics in elementary schools is an interesting study to discuss because of the different characteristics, namely between the nature of students and the nature of mathematics. Elementary school-age students are developing at the level of thinking. This is because the thinking stage of elementary school students is still not formal, even elementary school students in lower grades are still in the pre-concrete thinking stage (Kholiq, 2020). On the other hand, mathematics is a deductive, axiomatic, formal, hierarchical, abstract science, and is a meaningful language of symbols (Venturi, 2015; Vojkuvkova, 2012). Given these differences in characteristics, it is necessary to have a special ability from a teacher to bridge the world of children who have not thought deductively in order to understand the deductive world of mathematics.

The success of learning mathematics is influenced by the tendency to like mathematics as a challenge or referred to as a mathematical disposition (I. Kusmaryono et al., 2019; Mueller et al., 2011; Ulia \& Kusmaryono, 2021). However, efforts to improve mathematical disposition are still hindered by students' negative perceptions of mathematics. The results of previous studies show that for students mathematics is difficult, mathematics is a lot of memorizing 
formulas, mathematics is a lot of tasks, mathematics is not fun, and so on ( $\mathrm{Li}$ \& Schoenfeld, 2019; Schoenfeld, 2016). Actually, these negative perceptions (problems) refer to abstract mathematical objects and an inappropriate approach to learning mathematics. Therefore, it is necessary for teachers to be creative in managing mathematics learning (Kusmaryono et al., 2021; Rosyada \& Retnawati, 2021), especially in distance learning during the Covid-19 pandemic.

Referring to the fact that there are differences in these characteristics, it is clear how important it is to choose an approach to learning mathematics in elementary schools. The question is "What is the learning approach that can connect the realworld context and everyday life of elementary school-aged students with the study of abstract mathematics?" To answer this question, teachers are required to be able to manipulate abstract material by visualizing it into real life (contextual) that can be imagined or may have been or even often experienced by the students themselves (Laurens et al., 2018).

Basically, mathematics is very closely related to everyday life. One approach to learning mathematics that is oriented to the mathematization of everyday experiences and applying mathematics in everyday life is the realistic mathematics education approach (Laurens et al., 2018). The main concept of realistic mathematics education is meaningfulness (Prahmana et al., 2020).

The results of the summary of some literature from experts (Amala \& Ekawati, 2020; Kempa et al., 2019; Menon, 2015; Prahmana et al., 2020; Van Den Heuvel-Panhuizen, 2003) can be defined that the mathematics realistic education (RME) approach is an approach that uses or relates mathematics subject matter to realistic problems, namely problems (activities) experienced by humans in everyday life through the process of mathematization both horizontally and vertically. The RME learning approach emphasizes more on real contexts known to students and the process of constructing mathematical knowledge by students (Van Den Heuvel-Panhuizen, 2003).

The RME approach has advantages, namely: Mathematics lessons become more fun, the subject matter becomes easy to understand by students, students can build their own knowledge, and students feel valued in expressing opinions so that their self-confidence increases (Kempa et al., 2019; Laurens et al., 2018; Prahmana et al., 2020). The weaknesses of the RME approach are: it is not easy 
for teachers to encourage students to find various ways to solve problems, and it is not easy for teachers to provide assistance to students in order to rediscover the mathematical concepts learned (Kempa et al., 2019; Prahmana et al., 2020; Theodora \& Hidayat, 2018). In order to overcome the weaknesses of RME, it can be done through horizontal mathematization and vertical mathematization processes (Laurens et al., 2018).

A realistic problem does not always have to be a problem that exists in the real world and can be found in students' daily lives. A problem is called realistic if the problem can be imagined (imaginable) or real (real) in the minds of students (Van Zanten \& Van Den Heuvel-Panhuizen, 2021). A fictional story, a game, or even a formal form of mathematics can be used as a realistic problem (Amala \& Ekawati, 2020).

In realistic mathematics learning, realistic problems can be used as a foundation in building mathematical concepts (Kempa et al., 2019; Laurens et al., 2018). For this reason, students are expected to be more active in discussing and reflecting in order to construct mathematical concepts (Ardiyani \& Gunarhadi, 2018; Febriyanti et al., 2019). By applying a realistic mathematical approach, students will be able to build imagination and creative thinking skills in solving a problem (Kohar A.W. et al., 2021).

Imagination is a work of the mind in developing a broader thought than what has been seen, heard, and felt (Pelaprat \& Cole, 2011; Yuli \& Siswono, 2011). Imagination is the power of thought to imagine (in wishful thinking) or create images (paintings, essays, etc.) of events based on reality or one's general experience (Pelaprat \& Cole, 2011; Venturi, 2015). With imagination, humans develop something from simplicity to be more valuable in mind (Pelaprat \& Cole, 2011).

Talking about imagination is very closely related to creative thinking activities (creativity), on the other hand talking about creative thinking (creativity) cannot be separated from imagination (Tsaniyah \& Poedjiastoeti, 2017). Because creativity is the ability to produce something new and unique from the results of the thinking process (imagination) (Neto et al., 2019). Imagination is often said to be the basis of creative thinking activities. Creative people have many hidden piles of imagination in their brains (Arikan \& Unal, 2014). 
This study aims to investigate the effect of the RME approach on the imagination and creative thinking abilities of elementary school students in solving math problems. The results of this study are expected to provide benefits to elementary school teachers, namely (1) as consideration for implementing learning with the RME approach in elementary schools; (2) as an effort to bring mathematics (with abstract objects) closer to realistic problems according to the learning world of elementary school students; and (3) to develop imaginative and creative thinking skills in solving problems.

\section{METHODS}

This research is a qualitative research based on classroom reports (Eriksson et al., 2018; Hazzan \& Nutov, 2014). Where one class group is given the treatment of mathematics learning with a RME approach, then at the end of learning students complete the test. All important things that occur during learning activities are observed, recorded, and reported.

The method of data collection was done through written tests, observations, and interviews. The test instrument consists of mathematical questions about the material area of a quadrilateral area and social arithmetic. The observation instrument was in the form of an observation sheet for teacher and student activities during the learning process. Interview instrument in the form of a list of interview questions compiled in a semi-structured (Eriksson et al., 2018).

The research was conducted at Sultan Agung Islamic Elementary School, Semarang. The participants in this study consisted of a class teacher, 36 grade 6 students, and an observer. The class teacher is in charge of managing learning in the mathematics class with a mathematical realistic education approach. An observer notes and reports important things during the learning activity.

The problems presented in the learning are contextual problems. Researchers took two examples of mathematical problems that must be solved by students after participating in RME learning. These problems are about the area of a quadrilateral and social arithmetic as presented in the following table. 
Table 1. Mathematics Problems

\begin{tabular}{l} 
Problems \\
\hline $\begin{array}{l}\text { Which of the shaded quadrilat } \\
\text { biggest area? }\end{array}$ \\
Problem 1: \\
quadrea of the
\end{tabular}

Figure A

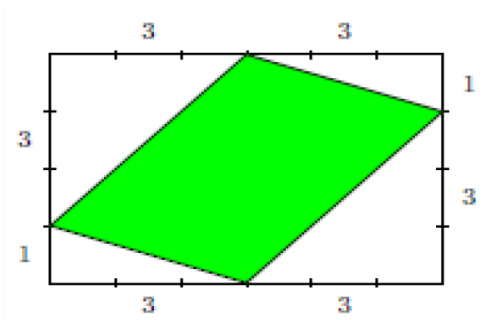

Figure B

\footnotetext{
Problem 2: $\quad$ 2,500.00 consists of 1 notebook and 2 pencils. Package B for IDR 2,000.00

In a shop selling several packages of stationery. Package A for IDR

Social

arithmetic If Dony wants to buy more books than pencils with IDR 5.500,00 how many books and pencils can he buy?
}

This research begins with carrying out mathematics learning in grade 6 elementary school for 3 meetings. Each lesson is carried out using the RME approach using the steps of (1) understanding the problem/ context, (2) explaining contextual problems, (3) solving contextual problems, (4) comparing and discussing answers, and (5) concluding. The first meeting discussed the material of the area of a quadrilateral. The second meeting discussed social arithmetic. In the third meeting, students were given a test in the form of problems to solve. Then, several students were selected purposively and interviewed in-depth to confirm the answers and the problem-solving process.

The written test results data were analyzed and grouped based on the characteristics and types of answers. The interview data were reduced and described qualitatively and validated by the triangulation method (Sandybayev, 2019). The conclusion of the research results is based on the triangulation validation of relevant sources, methods, and theories (Carter et al., 2014). 


\section{RESULT AND DISCUSSION}

\section{Results}

Based on observations, it can be reported that the implementation of learning is running according to the RME learning steps. The contextual problems presented can be understood by students. The teacher facilitates the discussion well. In the discussion students actively interact with group members. When concluding answers, various types of creative answers emerge.

The results of student responses to the test (problem) submitted were collected as many as 36 respondents. All answers have been carefully corrected and analyzed. The quality of students' answers is grouped into correct answers and wrong answers in the form of percentages.

Table 2. Quality of Student Answers

\begin{tabular}{lccc}
\hline \multirow{2}{*}{ Problems } & \multicolumn{2}{c}{ Answer Quality (\%) } & \multirow{2}{*}{ Total } \\
\cline { 2 - 3 } & Correct & Incorrect & \\
\hline Problem 1: & 31 & 5 & 36 \\
Area of the quadrilaterals & $(86,11 \%)$ & $(13.89 \%)$ & $(100.00 \%)$ \\
\hline Problem 2: & $24(66.67 \%)$ & 12 & 36 \\
Social arithmetic & & $(33.33 \%)$ & $(100.00 \%)$ \\
\hline \multicolumn{1}{c}{ Average } & $\mathbf{7 6 . 3 9 \%}$ & $\mathbf{2 3 . 6 1 \%}$ & -- \\
\hline
\end{tabular}

The results of student responses (Table 2) to Problem 1 there are $86.11 \%$ of respondents answered correctly, and in Problem 2 there are $66.67 \%$ of respondents answered correctly. Thus, it is said that on average there are more than half (most) of the respondents who managed to correctly answer the problems posed.

Problem 1 has been answered correctly by 31 respondents (See Table 2). After being analyzed, their answers were grouped based on the 
characteristics and methods of solving them. The description of the answers to problem 1 is presented in Table 3 below.

Table 3. Description of Answers to Problem 1

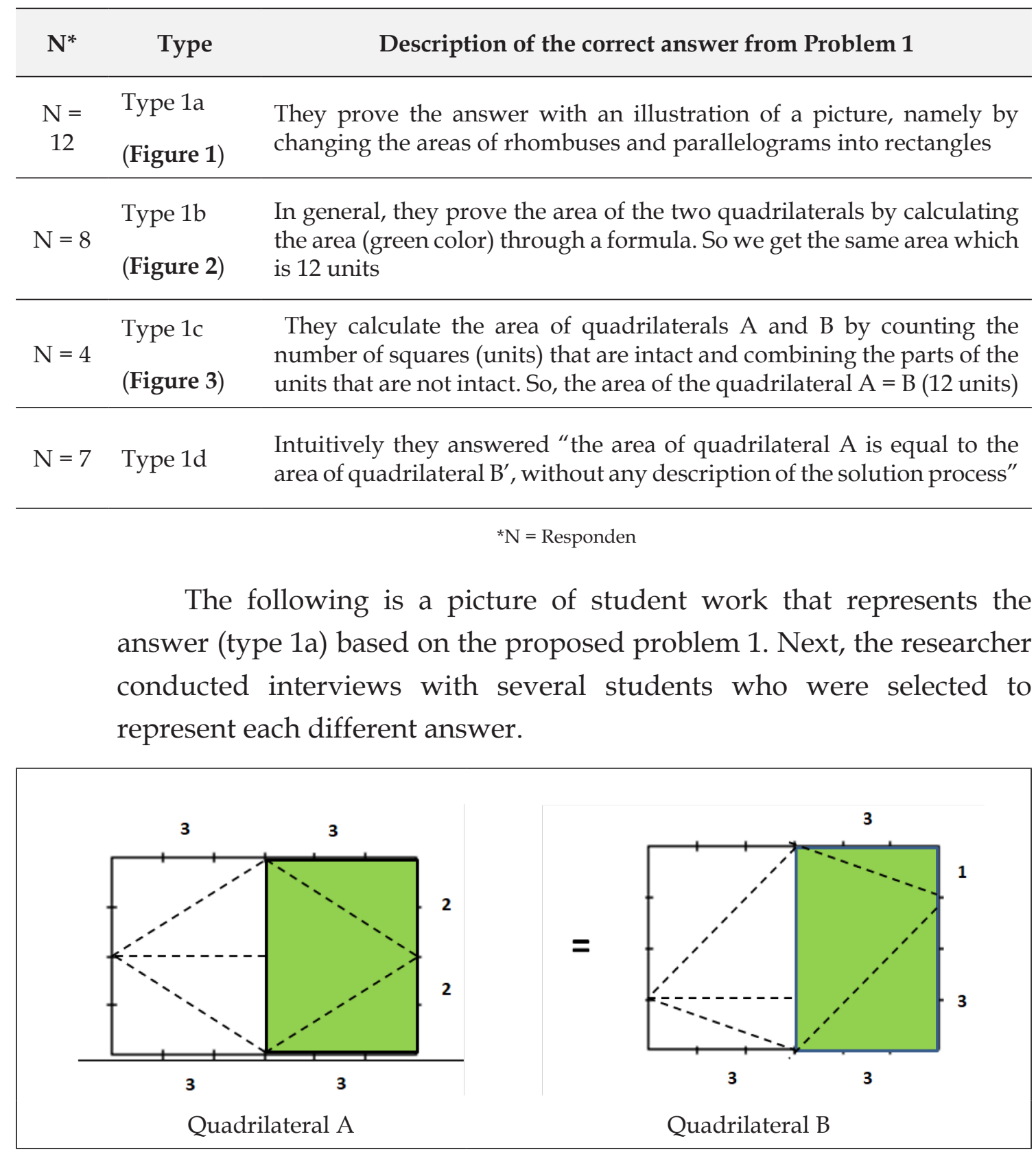

Figure 1. Student Answers (Type 1a) 
To confirm the answers in Figure 1, the researcher conducted interviews with students. Interviews were conducted in-depth to determine the imaginative thinking process and students' creative thinking skills in solving problems (problem 1).

$\begin{array}{lll}\text { Researcher } & : & \text { What do you think about when you face problem 1? } \\ \text { Student (S-1a) } & : & \text { I picture a rectangular field in my mind. } \\ \text { Researcher } & : & \text { Why did you convert that rectangle into a rectangle specifically? } \\ \text { Student (S-1a) } & : & \text { So that it is easy to compare the areas of the two quadrilaterals } \\ \text { Researcher } & : & \text { How do you prove that both quadrilaterals A and B have the same area? } \\ \text { Student (S-1a) } & : & \text { I moved the parts of the rectangle to the other congruent side so that it } \\ \text { Researcher } & : & \text { Why don't you calculate the area of a quadrilateral? }\end{array}$

Student (S-1a) : I think it will take a lot of time and a lot of energy.

The following is a picture of student work that represents the answer (type 1b) based on the proposed problem 1.

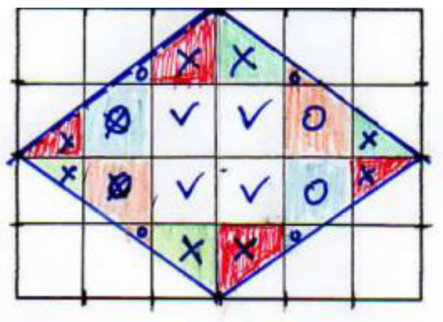

Quadrilateral A

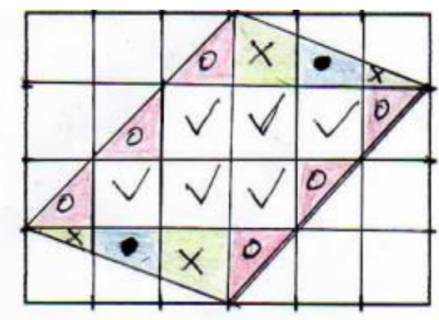

Quadrilateral B

Figure 2. Student Answers (Type 1b) 
To confirm the answers in Figure 2, the researcher conducted interviews with students. The following is an excerpt of the interview.

Researcher

Student (S-1b)

Researcher

Student (S-1b)

Researcher

Student (S-1b)

Researcher

Student (S-1b)

Researcher

Student (S-1b)
: What do you think when solving problem 1?

Based on experience, I will calculate the area bounded by the sides of a quadrilateral.

: How do you do it?

: $\quad$ The idea is, I count the complete units of the quadrilateral area

: What about areas (units) that are not intact?

: I combine incomplete units with other units so that they become whole.

: How's your calculation?

The area of rectangle $A=12$ units and the area of the rectangle $B=12$ units

: What conclusion did you get?

: Both quadrilaterals ( $A$ and $B$ ) have the same area of 12 units.

The following is a picture of student work that represents the answer (type 1c) based on the proposed problem 1.

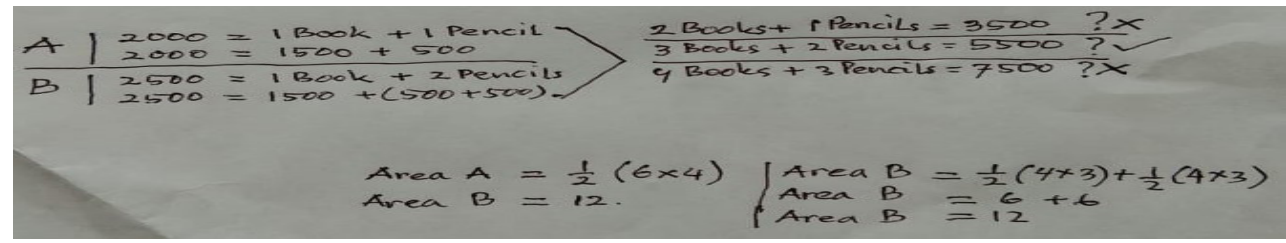

Quadrilateral A

Quadrilateral B

Figure 3. Student Answers (Type 1c)

To confirm the answers in Figure 3, the researcher conducted interviews with students. The following is an excerpt of the interview.

$\begin{array}{lll}\text { Researcher } & : & \text { What do you think when solving problem } 1 ? \\ \text { Student }(S-1 c) & : & \text { This problem is an experience I've had } \\ \text { Researcher } & : & \text { What is your idea to solve problem 1? } \\ \text { Student }(S-1 c) & : & \text { The area of A is half of the area of the rectangle. } \\ \text { Researcher } & : & \text { The area of area B is the area of two triangles. } \\ \text { Student }(S-1 c) & : & \text { What is your conclusion? }\end{array}$


The following is a picture of student work that represents the answer (type 1d) based on the proposed problem 1.

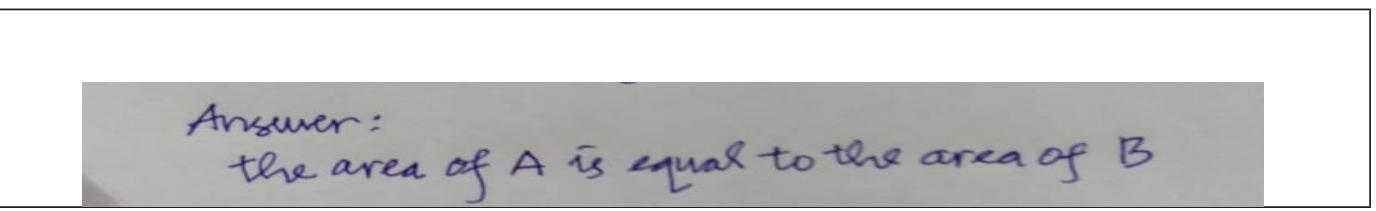

Figure 4. Student Answers (Type 1d)

To confirm the answers in Figure 4, the researcher conducted interviews with the students. The following is an excerpt of the interview.

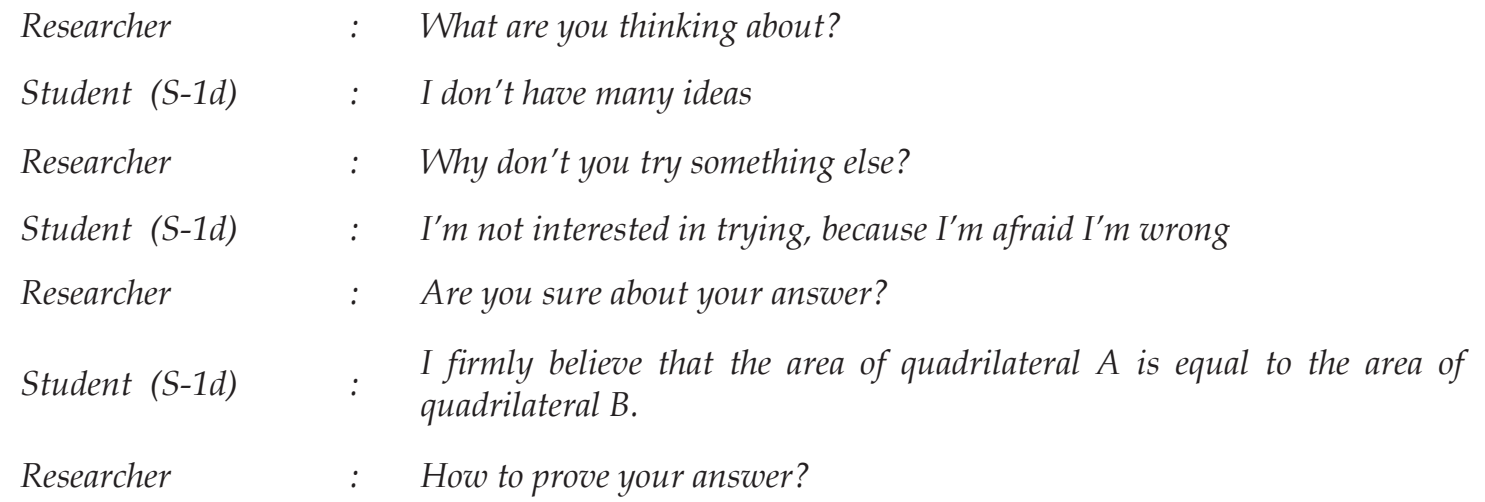

Student (S-1d) : I can't prove it analytically, but just physically comparing the two.

Problem 2 has been answered correctly by 24 respondents (see Table 2). After being analyzed, their answers were grouped based on the characteristics and methods of solving them. The description of the answers to problem 2 is presented in Table 4 below.

Table 4. Description of Answers to Problem 2

\begin{tabular}{ccc}
\hline $\mathbf{N}^{*}$ & Type & Description of the correct answer from Problem 2 \\
\hline $\mathrm{N}=7$ & $\begin{array}{c}\text { Type 2a } \\
\text { (Figure } 4)\end{array}$ & $\begin{array}{l}\text { They prove the answer through the illustration of the balance } \\
\text { model with the addition and subtraction technique. }\end{array}$ \\
$\mathrm{N}=6$ & Type 2b & They use the distribution table model \\
\hline $\mathrm{N}=$ & Type 2c & $\begin{array}{l}\text { In general, they do a trial and error until the correct answer is } \\
\text { obtained. }\end{array}$ \\
\hline 11 & (Figure 6) & \\
\hline
\end{tabular}


Interviews were also conducted with several students selected to represent each different answer. The purpose of the interview was to find out about the imaginative thinking process and students' creative thinking skills in solving problems (problem 2). It should be noted that grade 6 elementary school students have not been introduced to a two-variable linear equation system so that students' answers are purely the result of their creativity after participating in learning with a mathematics realistic education approach. The following is a picture of student work that represents the answers (type 2a) based on the proposed problem 2 .

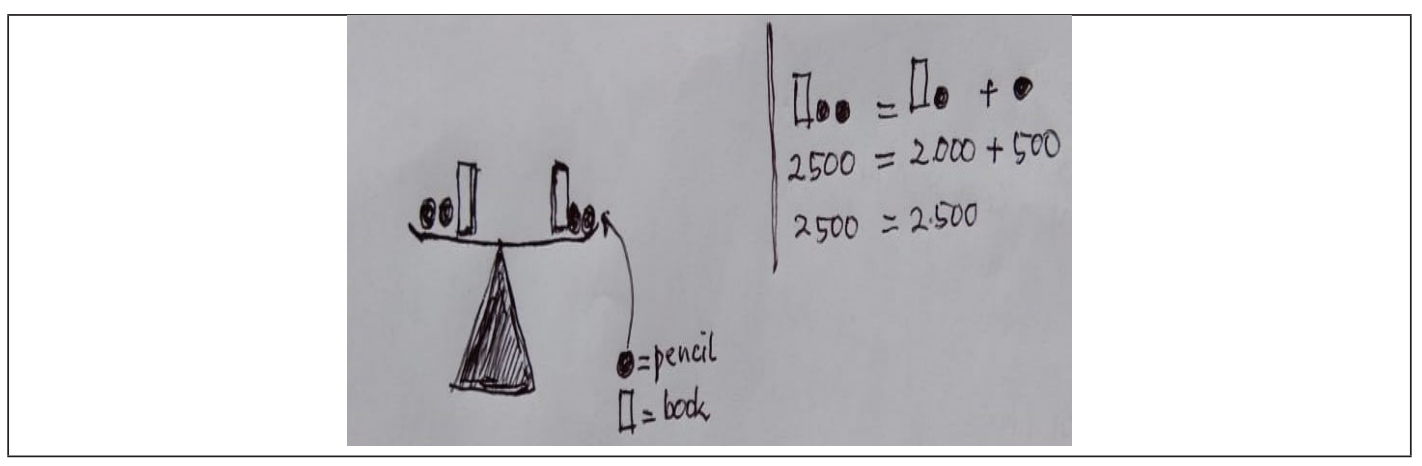

Figure 5. Student Answers (Type 2a)

To confirm the answers in Figure 5, the researcher conducted interviews with students. The following is an excerpt of the interview.

\begin{tabular}{|c|c|c|}
\hline Researcher & $:$ & What do you think (imagine) about this problem \\
\hline Student $(S-2 a)$ & : & I imagine this matter as a balance \\
\hline Researcher & : & Where did you get the scale idea from? \\
\hline Student $(S-2 a)$ & : & This is my experience in daily life \\
\hline Researcher & : & Why did you add 1 pencil to the right side of the \\
\hline Student $(S-2 a)$ & ${ }^{\circ}$ & $\begin{array}{l}\text { The goal is that the left and right sides are bal } \\
1 \text { pencil. }=500 \text { and } 1 \text { book }=1,500\end{array}$ \\
\hline Researcher & : & What is the result of solving this problem? \\
\hline & & $=(3 \times 1.500)+(2 \times 500)$ \\
\hline Student $(S-2 a)$ & & $=4.500+1.000$ \\
\hline
\end{tabular}


The following is a picture of student work that represents the answer (type $2 \mathrm{~b}$ ) based on the proposed problem 2 .

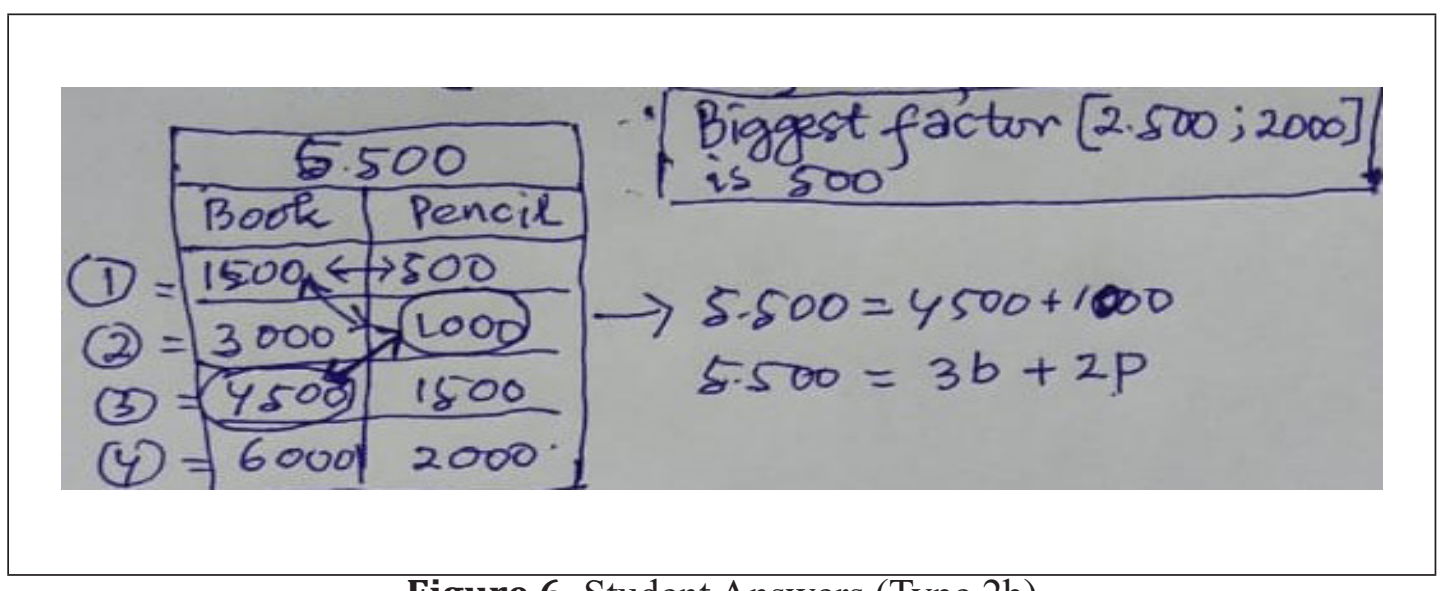

Figure 6. Student Answers (Type 2b)

To confirm the answers in Figure 6, the researcher conducted interviews with students. The following is an excerpt of the interview.

Researcher

Student $(S-2 b)$

Researcher

Student (S-2b)

Researcher

Student (S-2b)

Researcher

Student $(S-2 b)$
: What is your goal in finding the greatest common factor of 2,500 and 2,000?

The greatest common factor of 2,500 and 2,000 is 500. This number 500 is the basis for initial calculations to estimate the price of goods, 1 pencil $=500$ and 1 book $=1,500$

Why did you put the number 500 in the pencil column?

: In order to fulfill the equation that 1 book +2 pencils $=2,500$

: Why do you use distribution tables in solving problem 1 ?

: $\quad$ To help express ideas so that calculations are more real

: What conclusions can you draw from the table?

: $\quad$ So the pair of goods with a price of IDR 5,500.00 is 3 notebooks and 2 pencils.

The following is a picture of student work that represents the answer (type 2c) based on the proposed problem 2. 


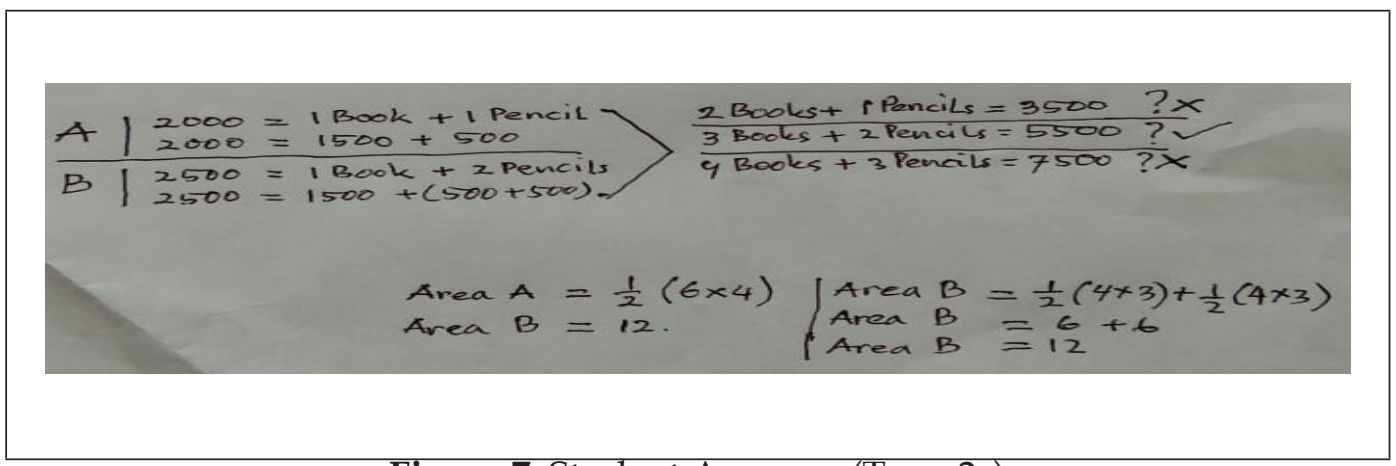

Figure 7. Student Answers (Type 2c)

To confirm the answers in Figure 7, the researcher conducted interviews with students. The following is an excerpt of the interview.

\begin{tabular}{|c|c|c|}
\hline Researcher & $:$ & How do you think about how to solve problem 1? \\
\hline Student $(S-2 c)$ & : & I can imagine this problem as not difficult. \\
\hline Researcher & : & How can you determine the price of 1 book $=1,500$ and 1 pencil $=500 ?$ \\
\hline Student $(S-2 c)$ & : & $\begin{array}{l}\text { This is the result of several tries (trial and error) with the assumption that } \\
\text { the price of the book is more expensive than the price of a pencil }\end{array}$ \\
\hline Researcher & : & $\begin{array}{l}\text { Why did you choose that the price of } 1 \text { book }=1,500 \text { and } 1 \text { pencil }=500 \text {, not } \\
\text { the other way around } 1 \text { book }=500 \text { and } 1 \text { pencil }=1,500 ?\end{array}$ \\
\hline Student $(S-2 c)$ & : & $\begin{array}{l}\text { In everyday experience, the price of books is more expensive than the price } \\
\text { of pencils and I buy more books than pencils. }\end{array}$ \\
\hline Researcher & : & How to solve problem 1 ? \\
\hline Student $(S-2 c)$ & & $\begin{array}{l}\text { After several times I tried to compile a price list of goods, finally found for } \\
\text { IDR 5,500.00 I can buy } 3 \text { notebooks and } 2 \text { pencils. }\end{array}$ \\
\hline
\end{tabular}

\section{Discussion}

Based on observations, it was reported that learning was carried out in accordance with the steps and principles of the RME approach. The RME learning steps implemented include: (1) starting the lesson by asking "real" problems (questions) according to the experience and level of student's knowledge so that students are involved in meaningful learning; (2) problems are directed according to the objectives to be achieved; (3) students develop or create informal symbolic models of the problems or problems posed; and (4) learning takes place interactively where during discussions students explain and give reasons for their friends' answers, 
express disagreements, look for other alternative solutions, and reflect on each step taken on the results of the lesson. Of course, learning mathematics RME is very appropriate and useful for children aged 7-11 years, in the field of mathematics (Ardiyani \& Gunarhadi, 2018; Kholiq, 2020).

Imagination thinking that takes place in students (S-1a; S-1b; S-1c; S-2a; S-2c) is an experience they have ever experienced. Students' thinking imagination (S-1a; S-1b; S-1c; S-2a; S-2c) is referred to as the process of rebuilding the perception of an object that is first given the perception of understanding from previous knowledge (Beyerl et al., 2016; Budiman \& Apriani, 2019). In general, they already have a strong imagination about the rectangle (S-2a), triangle (S-1c), and the balance model (S-2a). Through these experiences, they reconstruct their knowledge to solve the problems they face (Crooks \& Alibali, 2013).

Meanwhile, students (S-2b) stated that the solution with the distribution table model made the experience more real. Student (S-2b) added that through the distribution table, the right pair of items could be found at a price of IDR 5,500.00, namely 3 notebooks and 2 pencils. Students (S-2a and $\mathrm{S}-2 \mathrm{~b})$ based on their imaginations can make mathematical symbolic models (Mann, 2006). Student (S-2c) stated that problem 2 to determine the price of books and pencils is not difficult even though by trial and error. Student (S-2c) imagining that the price of a book is more expensive than the price of a pencil is true. On the other hand, students (S-1d) who do not have many ideas and are less imaginative, do not dare to take risks for fear of making mistakes. They do not realize that the ability to think, examine, understand, understand, and feel something imagined will actually be processed in our imagination (Pelaprat \& Cole, 2011).

Regarding the results of this study, it can be stated that through Realistic Mathematics Education learning, children (students) can learn contextual things and they are increasingly developing their imagination (thinking power) (Pelaprat \& Cole, 2011;Putrietal., 2019; Ulandarietal., 2019). The power of imagination can be seen from their ability to reveal more information from learning sources, express ideas or ideas about existing problems (Pelaprat \& Cole, 2011; Wang et al., 2010; Yuli \& Siswono, 2011). 
Talking about creative thinking skills, students' work (see Figure 1 to Figure 7) which varies differently can be said to be a reflection of students' creative thinking abilities. This shows that the students' work has original (creative) ideas that are different from most of the other students (Maharani et al., 2017). Operationally, it has fulfilled the element of creativity which is formulated as "the ability that reflects fluency, flexibility (flexibility), and originality in thinking, as well as the ability to elaborate (develop, enrich, detail) an idea (Yuli \& Siswono, 2011).

Creativity has been shown by students (S-1a; S-1b; S-1c; S-2a; S-2b; and $S-2 c)$, they have the ability to make new combinations based on existing data, information, or elements (Mann, 2006). On the other hand, students (S-2a) have used their imagination through the use of concrete materials with a balance model to solve problem 2 (Otten et al., 2019). Students stated that it is realistic to achieve a state of balance by adding 1 (one) pencil. The balance model for solving problem 2 (see Figure 4) is more often used by students who have algebraic experience related to physical experiences in everyday life (Otten et al., 2019).

Meanwhile, students (S-2b) in the first step use their imagination by finding the largest common factor of 2,500 and 2,000, which is 500, then using the goods price distribution table to compile a mathematical model (bachelor \& biology 2020) so that the right answer is obtained. Creativity is also shown by students (S-2c) students (S-2c) with the courage to do trial and error through the presentation of various answer choices. But finally, students (S-2c) can find the right answer for solving problem 2 . This condition can be said that students (S-2b and S-2c) have convergent thinking (creative thinking), namely the ability to find many possible answers to a problem, with an emphasis on quantity, appropriateness, and variety of answers (Lubart, 2016).

Summarizing from this discussion, a red line can be drawn that imaginative ability is closely related to the ability to think creatively. Creative and imaginative thinking is a person's ability to hone his creative and imaginative powers in creating new things (Mann, 2006). It is not wrong if students who are able to think creatively are always followed by high imaginative abilities (Birgili, 2015; Mann, 2006). 
The development of students' imaginative and creative thinking abilities cannot be separated from the application of the RME approach by the teacher. The RME approach provides students' learning experiences according to the real context of students' lives and their level of knowledge (Van Zanten \& Van Den Heuvel-Panhuizen, 2021). Based on the learning experience, students can develop or create symbolic models of the problems posed. So that students can imagine and think creatively to find alternative problem solving (Ulandari et al., 2019). Of course, learning mathematics RME is very appropriate and useful for children aged 7-11 years, in the field of mathematics (Ardiyani \& Gunarhadi, 2018; Wahyudi, 2016).

\section{CONCLUSION}

Imaginative ability is closely related to the ability to think creatively. Students with high creative thinking skills in their thinking activities always begin with high imagination power, then that imagination is actualized in actions to solve problems. Meanwhile, students who are less creative generally lack ideas, lack imagination, and do not dare to try. The application of the realistic mathematics education learning approach has a positive influence, namely encouraging the development of students' imaginative power and creative thinking skills in solving problems. The principles of RME are in line with the objectives of learning mathematics, namely to equip them with the ability to think logically, realistically, analytically, systematically, critically, and creatively. 


\section{REFERENCES}

Amala, M. A., \& Ekawati, R. (2020). The profile of horizontal and vertical mathematization process ofjJunior high school student with High mathematical ability in solving contextual problem of fraction. Jurnal Riset Pendidikan Dan Inovasi Pembelajaran Matematika (JRPIPM), 3(2), 5260. https:// doi.org/10.26740/jrpipm.v3n2.p52-60

Ardiyani, S. M., \& Gunarhadi, R. (2018). Realistic mathematics education in cooperative learning viewed from learning activity. Journal on Mathematics Education, 9(2), 301-310. https:// doi.org/10.22342/jme.9.2.5392.301-310

Arikan, E. E., \& Unal, H. (2014). Development of the structured problem posing skills and using metaphoric perceptions. European Journal of Science and Mathematics Education, 2(3), 155-166.

Beyerl, K., Putz, O., \& Breckwoldt, A. (2016). The role of perceptions for community-based marine resource management. Frontiers in Marine Science, 3(2), 1-15. https:/ / doi.org/10.3389/fmars.2016.00238

Birgili, B. (2015). Creative and critical thinking skills in problem-based learning environments. Journal of Gifted Education and Creativity, 2(2), 71-71. https:/ / doi.org/10.18200/jgedc.2015214253

Budiman, W., \& Apriani, E. (2019). Students' perception of lecturers' role in enhancing EFL learners' communication ability. 3rd English Language and Literature International Conference (ELLiC), 3(1), 223-237.

Carter, N., Bryant-Lukosius, D., Dicenso, A., Blythe, J., \& Neville, A. J. (2014). The use of triangulation in qualitative research. Oncology Nursing Forum, 41(5), 545-547. https:/ / doi.org/10.1188/14.ONF.545-547

Crooks, N. M., \& Alibali, M. W. (2013). Noticing relevant problem features: Activating prior knowledge affects problem solving by guiding encoding. Frontiers in Psychology, 4(11), 1-10. https:// doi.org/10.3389/ fpsyg.2013.00884

Eriksson, E., Boistrup, L. B., \& Thornberg, R. (2018). A qualitative study of primary teachers' classroom feedback rationales. Educational Research, 60(2), 189-205. https:/ / doi.org/10.1080/00131881.2018.1451759 
Febriyanti, F., Bagaskorowati, R., \& Makmuri, M. (2019). The effect of the realistic mathematics education (RME) approach and the initial ability of students on the ability of student mathematical connection. International Journal for Educational and Vocational Studies, 1(3), 153-156.

Hazzan, O., \& Nutov, L. (2014). Teaching and learning qualitative research $\approx$ Conducting qualitative research. The Qualitative Report, 19(1), 1-29. https:/ / doi.org/10.46743/2160-3715/2014.1218

Kempa, R., Laurens, T., Leasa, M., Rafafy Batlolona, J., Batlolona, M., \& Julian Enriquez, J. (2019). Comparison of problem based learning and realistic mathematics education to improve students academic performance. Jurnal Pendidikan Progresif, 9(2), 185-197. https://doi.org/10.23960/jpp. v9.i2.201905

Kholiq, A. (2020). How is Piaget's theory used to test the cognitive readiness of early childhood in school? Indonesian Journal of Early Childhood Education Studies, 9(1), 24-28. https:/ / doi.org/10.15294/ijeces.v9i1.37675

Kohar A.W., Fachruddin, Achmad D., \& Widadah, S. (2021). Facilitating students' multiple intelligences through RME: A learning trajectory of volume and surface area measurement. Inomatika, 3(1), 27-50. https:// doi.org/10.35438/inomatika.v3i1.248

Kusmaryono, I., Suyitno, H., Dwijanto, D., \& Dwidayati, N. (2019). The effect of mathematical disposition on mathematical power formation: Review of dispositional mental functions. International Journal of Instruction, 12(1). https://doi.org/10.29333/iji.2019.12123a

Kusmaryono, I., Jupriyanto, J., \& Kusumaningsih, W. (2021). A systematic literature review on the effectiveness of distance learning: Problems, opportunities, challenges, and predictions. International Journal of Education, 14(1), 62-69. https:/ / doi.org/10.17509/ije.v14i1.29191

Laurens, T., Batlolona, F. A., Batlolona, J. R., \& Leasa, M. (2018). How does realistic mathematics education (RME) improve students' mathematics cognitive achievement? Eurasia Journal of Mathematics, Science and Technology Education, 14(2), 569-578. https://doi.org/10.12973/ejmste/76959

Li, Y., \& Schoenfeld, A. H. (2019). Problematizing teaching and learning mathematics as "given" in STEM education. International Journal of STEM Education, 6(1), 1-10. https:/ / doi.org/10.1186/s40594-019-0197-9 
Lubart, T. (2016). Creativity and convergent thinking: Reflections, connections and practical considerations. RUDN Journal of Psychology and Pedagogics, 1(4), 7-15. https:/ / doi.org/10.22363/2313-1683-2016-4-7-15

Maharani, H. R., Sukestiyarno, S., \& Waluya, B. (2017). Creative thinking process based on Wallas model in solving mathematics problem. International Journal on Emerging Mathematics Education, 1(2), 177-188.

Mann, E. L. (2006). Creativity: The essence of mathematics. Journal for the Education of the Gifted, 30(2), 236-260. https:/ / doi.org/10.4219/jeg-2006-264

Menon, U. (2015). Mathematization vertical and horizontal. STEME 5 International Conference to Review Research on Science, Technology and Mathematics Education, Conference Proceedings., May, 260-267.

Mueller, M., Yankelewitz, D., \& Maher, C. (2011). Sense Making as Motivation in Doing Mathematics: Results from Two Studies. The Mathematics Educator, 20(2), 33-43.

Neto, J. C., Filipe, J. A., \& Caleiro, A. B. (2019). Creativity and innovation: A contribution of behavioral economics. International Journal of Innovation Studies, 3(1), 12-21. https:/ / doi.org/10.1016/j.ijis.2019.06.003

Otten, M., Van den Heuvel-Panhuizen, M., \& Veldhuis, M. (2019). The balance model for teaching linear equations: a systematic literature review. International Journal of STEM Education, 6(1), 1-21. https:/ / doi. org/10.1186/s40594-019-0183-2

Pelaprat, E., \& Cole, M. (2011). “Minding the Gap": Imagination, creativity and human cognition. Integrative Psychological and Behavioral Science, 45(4), 397-418. https://doi.org/10.1007/s12124-011-9176-5

Prahmana, R. C. I., Sagita, L., Hidayat, W., \& Utami, N. W. (2020). Two decades of realistic mathematics education research in Indonesia: A survey. Infinity Journal, 9(2), 223. https:/ / doi.org/10.22460/infinity.v9i2.p223-246

Putri, S. K., Hasratuddin, H., \& Syahputra, E. (2019). Development of learning devices based on realistic mathematics education to improve students' spatial ability and motivation. International Electronic Journal of Mathematics Education, 14(2), 393-400. https://doi.org/10.29333/iejme/5729

Rosyada, M. N., \& Retnawati, H. (2021). Challenges of mathematics learning with heuristic strategies. Al-Jabar: Jurnal Pendidikan Matematika, 12(1), 
161-173. http://ejournal.radenintan.ac.id/index.php/al-jabar/article/ view /2014/1564

Sandybayev, A. (2019). Reflection of triangulation, case Study of Innovation Behaviors in the UAE Travel Agencies Organizations. 1(4), 10-15.

Schoenfeld, A. H. (2016). Learning to think mathematically: Problem solving, metacognition, and sense making in mathematics. Journal of Education, 196(2), 1-38. https:/ / doi.org/10.1177/002205741619600202

Theodora, F. R. N., \& Hidayat, D. (2018). The use of realistic mathematics education in teaching the concept of equality. JOHME: Journal of Holistic Mathematics Education, 1(2), 104-113. https://doi.org/10.19166/johme. v1i2.913

Tsaniyah, A. B., \& Poedjiastoeti, S. (2017). Moge learning model to improve creative thinking skills. International Journal of Education and Research, 5(1), 165-172.

Ulandari, L., Amry, Z., \& Saragih, S. (2019). Development of learning materials based on realistic mathematics education approach to improve students' mathematical problem solving ability and self-efficacy. International Electronic Journal of Mathematics Education, 14(2), 375-383. https:// doi. org/10.29333/iejme/5721

Ulia, N., \& Kusmaryono, I. (2021). Mathematical disposition of students', teachers, and parents in distance learning: A survey. Premiere Educandum : Jurnal Pendidikan Dasar Dan Pembelajaran, 11(1), 147-159. https:// doi. org/10.25273/pe.v11i1.8869

Van Den Heuvel-Panhuizen, M. (2003). The didactical use of models in realistic mathematics education: An example from a longitudinal trajectory on percentage. Educational Studies in Mathematics, 54(1), 9-35. https:// doi. org/10.1023/B:EDUC.0000005212.03219.dc

Van Zanten, M., \& Van Den Heuvel-Panhuizen, M. (2021). Mathematics curriculum reform and its implementation in textbooks: Early addition and subtraction in realistic mathematics education. Mathematics, 9(7), 1-20. https:/ / doi.org/10.3390/math9070752

Venturi, G. (2015). Hilbert between the formal and the informal side of mathematics. Rev. Int. Fil., Campina, 38(2), 5-38. 
Vojkuvkova, I. (2012). The van Hiele model of geometric thinking. WDS'12 Proceedings of Contributed Papers, 1, 72-75.

Wahyudi. (2016). The development of realistic mathematics education (RME) model for the improvement of mathematics learnings of primary teacher education program (PGSD) students of teacher training and education faculty (FKIP) of sebelas maret university in kebumen. Proceeding The 2 nd International Conference On Teacher Training and Education Sebelas Maret University, 2(1), 369-381.

Wang, W.-C., Lee, C.-C., \& Chu, Y.-C. (2010). A brief review on developing creative thinking in young children by mind mapping. International Business Research, 3(3), 233-238. https:/ / doi.org/10.5539/ibr.v3n3p233 